\title{
Double row spacing and drip irrigation as technical options in energy sorghum management
}

\author{
Neri Roncucci, ${ }^{1}$ Federico Triana, ${ }^{1}$ Cristiano Tozzini, ${ }^{1}$ Enrico Bonari, ${ }^{1,2}$ Giorgio Ragaglini ${ }^{1}$ \\ ${ }^{1}$ Istituto di Scienze della Vita, Scuola Superiore Sant'Anna, Pisa; ${ }^{2}$ Centro di Ricerca \\ Interuniversitario Biomasse da Energia, San Piero a Grado (Pisa), Italy
}

\begin{abstract}
The effect of two row spacing configurations and four water supply levels was investigated on sweet and fibre sorghum in Central Italy for two consecutive years. Results highlighted the influence of both irrigation and row spatial configuration on crop productivity. Indeed, several studies have pointed out the positive response of sorghum to irrigation in Mediterranean climate, as in this environment water stress represents one of the main limiting factors on crop productivity. On the other hand, few attempts have been made to explore the role of row spacing on energy sorghum productivity. Results outlined an average increase in sorghum dry biomass yield ranging from $+23 \%$ to $+79 \%$ at variable rates of water supply as compared to rainfed control. The positive effect of irrigation was also observed on leaf area index and radiation use efficiency. Moreover, we observed a crop yield increase, from $9 \%$ to $20 \%$, under double row spacing compared to the standard planting pattern (i.e. single row spacing). Finally, it was confirmed the efficient use of water by sorghum and the great ability of sorghum to
\end{abstract}

Correspondence: Giorgio Ragaglini, Istituto di Scienze della Vita, Scuola Superiore Sant'Anna, Piazza Martiri Libertà, 33, 56127 Pisa, Italy.

E-mail: g.ragaglini@sssup.it

Key words: double-cropping, Mediterranean environment, plant spatial distribution, twin row, water agronomic efficiency.

Acknowledgements: Netafim Ltd. is gratefully acknowledged for the financial support and for providing the irrigation facility. Syngenta Seeds S.p.A is gratefully acknowledged for providing the seeds of the two sorghum varieties. The authors would like to acknowledge the CRIBE technical staff, particularly Fabio Taccini, Sergio Cattani and Nico Viligiardi. Special thanks are also due to Valentina Giulietti, Federico Dragoni, Maria Valentina Lasorella and Aung Kyaw Lwin from the Institute of Life Sciences for their help in collecting data.

Conference presentation: SIA XLII Congress, Reggio Calabria, 2013.

Received for publication: 13 November 2013.

Revision received: 22 January 2014.

Accepted for publication: 22 January 2014.

(C) Copyright N. Roncucci et al., 2014

Licensee PAGEPress, Italy

Italian Journal of Agronomy 2014; 9:563

doi:10.4081/ija.2014.563

This article is distributed under the terms of the Creative Commons Attribution Noncommercial License (by-nc 3.0) which permits any noncommercial use, distribution, and reproduction in any medium, provided the original author(s) and source are credited. increase its biomass yield in response to increasing volumes of water supplied. Therefore, this work suggests how row spacing configuration and drip irrigation could be feasible technical options to increase sorghum biomass yields in Mediterranean environments. These techniques should be experienced by farmers towards a sustainable intensification of current cropping systems.

\section{Introduction}

Sorghum (Sorghum bicolor (L.) Moench) is an interesting candidate for biomass production since it is highly productive and versatile (Garofalo et al., 2011). Sorghum is a C4 species native to tropical zones though it shows a wide adaptability to different environmental conditions, including those with limited soil fertility and modest water availability (Zegada-Lizarazu and Monti, 2012). Indeed, morphological and $\mathrm{C} 4$ pathway confer to the species an efficient $\mathrm{CO}_{2}$ fixation, a high water use efficiency and a great drought tolerance owing to crop's ability to overcome periods of scarcity by slowing down its growth (Mastrorilli et al., 1995; Cosentino, 1996). Furthermore, the interest for this crop arises from the relatively simple technique of cultivation that allows sorghum to be grown with low input techniques (ZegadaLizarazu and Monti, 2012). For the above-mentioned reasons sorghum represents one of the annual crops potentially more interesting for biofuel production and energy purposes. In relation to its uses many botanical varieties and hybrids have been developed: among the cultivated sorghum genotypes grain, fibre, forage and sugar production traits have been selected (Zegada-Lizarazu and Monti, 2012). Sorghum genotypes that best fit to the energy transformation are the fibre and the sweet ones (hereinafter both referred to as energy sorghum), as they are characterized by a high biomass production, thick and pithy stems with variable sugar content (El Bassam, 1998; Barbanti et al., 2006). The main energetic destinations of energy sorghum are the production of electricity and/or heat through thermochemical processes and the production of ethanol or biogas through biological processes (Monti and Venturi, 2003; Amaducci et al., 2004; Antonopoulou et al., 2008). The fast growing ability of sorghum and its short growth cycle allow to introduce the crop in rotational cropping or in double-cropping systems, thus generating additional feedstock for bioenergy utilization (Heggenstaller et al., 2008; Pin et al., 2011). However, in Mediterranean areas one of the main limiting factors of summer cropping is water. Additionally, in double-cropping system the risk of soil moisture shortage may be worsened (Goff, 2010). Irrigation could thus be an important technique to increase sorghum yields at sites with poor water supply (Garofalo et al., 2011; Habyarimana et al., 2004a; Berenguer and Faci, 2001; Curt et al., 1995). Nevertheless, water availability and quality in the next future have been questioned and much attention will have to be paid on how to allocate water among different uses (Wallace, 2000).

Beyond water, row spacing may exert an important role on crop pro- 
ductivity. Some studies conducted on grain sorghum and maize have highlighted a greater productivity with double row planting pattern (Fukai and Foale, 1988; Gozubenli et al., 2004; Shakarami and Rafiee, 2009). On the other hand, few attempts have been made to explore the role of row spacing on biomass productivity of energy sorghum. Data from a series of experiments conducted in the USA suggest that the use of narrow row spacing can increase sweet sorghum yields (from $25 \%$ to 50\%) (Kresovich and Lawhon, 1981). Moreover, in East Australia Martin and Kelleher (1984) indicated that narrow row spacing at $30 \mathrm{~cm}$ gave higher sweet sorghum yields compared to $75 \mathrm{~cm}$ and $105 \mathrm{~cm}$.

Nevertheless, the determination of the optimum row spacing requires taking into account the productive potential of the location (Godsey et al., 2012; Habyarimana et al., 2004a). Kresovich and Lawhon (1981) highlighted the influence of the length of the growing season on productivity of narrow row spaced sorghum: the adoption of narrow row spacing can increase sorghum yields where the growing season is short, while its use is less significant in long growing seasons. For that reason, managing row distance could be an important technical option for improving yields in northern latitudes (Zegada-Lizarazu and Monti, 2012) or in double-cropping systems where sorghum needs to fit a short growing season between two winter crops.

Therefore, the aim of the present research was to evaluate the responses of sorghum, managed as a double cropping, to drip irrigation under Mediterranean climate conditions. Specifically, the objectives were to compare: i) two sorghum varieties (a fibre and a sweet one); ii) three different levels of water supply, provided by drip irrigation system, and a rainfed control; iii) two row spacing configurations, though maintaining the same population density.

\section{Materials and methods}

A field trial was established for two consecutive years in spring 2012 and 2013, at the Interdepartmental Centre of Agro-Environmental Researches (CIRAA) of the University of Pisa ( $43^{\circ} 40^{\prime}$ lat. N; $10^{\circ} 23^{\prime}$ long. E), in San Piero a Grado (Pisa), Italy. The characterization of the soils where the trial was conducted in 2012 and 2013 is given in Table 1.

The trial was designed to compare two different varieties (V) of sorghum, a fibre (Biomass 133) and a sweet one (Sucro 506). Both V were planted with two different row spacing configurations (RSC): single row (SR) with rows equally spaced at $50 \mathrm{~cm}$, and double row (DR) spaced $20 / 80 \mathrm{~cm}$. Moreover, four water supply levels (WS) were defined according to the daily potential evapotranspiration: a rainfed control receiving no water supply ( $0 \mathrm{ETP}$ ), a treatment receiving $50 \%$ of the potential evapotranspiration (50 ETP), another receiving $100 \%$ of the potential evapotranspiration (100 ETP) and a fourth receiving $150 \%$ of the potential evapotranspiration (150 ETP).

The trial had a strip-split-plot design, with WS as main factor, RSC as strip factor and $\mathrm{V}$ as plot factor. Four replicates were established. Four main plots, sized $9 \times 20 \mathrm{~m}$, were divided into two subplots $(4.5 \times 20 \mathrm{~m})$ and assigned to the two-row spacing. Within each subplot two sub-sub- plot were defined $(4.5 \times 10 \mathrm{~m})$ and assigned to the varieties. The trial covered a total area of $2880 \mathrm{~m}^{2}$. In both years/sites seedbed preparation was performed with a disk harrowing $(20 \mathrm{~cm}$ depth) as soon as the preceding crop (forage grasses) was harvested. Seeding was conducted on June 1, 2012 and on May 27, 2013 by means of a plot seeder. Seed density was kept equal between SR and DR treatments ( 25 seeds $\mathrm{m}^{-2}$ ). The crop received nitrogen fertilization with $100 \mathrm{kgN} \mathrm{ha}^{-1}$, in the form of urea; fertilizer was uniformly broadcasted on soil surface on July 4, 2012 and on July 10, 2013. Weed control was never necessary in both years.

The irrigation facility consisted of three automated valves, providing water to three sectors of $720 \mathrm{~m}^{2}$ each. Drip irrigation pipes were placed 1 meter apart; pipes were positioned in the inter-row and within the double row in the SR and DR systems, respectively. The distance of drippers was $30 \mathrm{~cm}$ with a dripper flow rate of 1 litre per hour. In 2012 irrigation started on July 9, and ended at harvest, on August 28. In 2013 irrigation started on July 3, and ended at harvest, on September 3. Daily potential ETP was estimated through the FAO Penman-Monteith equation (Allen et al., 1998) from daily climatic data gathered from the nearest weather station (located less that $500 \mathrm{~m}$ from the experiment sites). Irrigation was scheduled every two days.

Crop development was monitored throughout the growing season by measuring the phenological stages. Measurements were taken on representative plant samples within the subplots. A total of seven and six measures were recorded along the 2012 and 2013 growing seasons respectively. Phenological stages were recorded using the extended BBCH scale, which is expressed in decimal code and is divided into principal and secondary growth stages (BBCH Monograph, 2001).

Crop productivity and its responses to the different treatments were assessed by destructive sampling at harvest (August 28, 2012 and September 3, 2013). In each subplot an area of $2 \mathrm{~m}^{2}$ was harvested. Border plants from the outer rows were not included in the sampling area. The aboveground fresh yield in each of the sampled areas was recorded. Sub-samples were partitioned into stems, leaves and inflorescences, and dried at a temperature of $60^{\circ} \mathrm{C}$ in a forced-air oven until constant weight. Partitioned dry yield and dry matter concentration were then calculated.

Measures of the canopy were performed throughout the two growing years. Specifically, leaf area index (LAI) was estimated at regular intervals by means of a leaf canopy analyser (SunScan, Delta-T Devices Ltd.).

Furthermore, radiation use efficiency (RUE) was calculated using data on intercepted PAR (iPAR) and the aboveground dry biomass production. iPAR was calculated as a fraction of total incident PAR for every sampling point using the following equation:

$$
\text { iPAR }=\frac{\text { PARin }- \text { PARtr }}{\text { PARin }}
$$

where PARin is the SunScan measure of incident PAR $\left(\mathrm{mol} \mathrm{m}^{-2} \mathrm{~s}^{-1}\right)$, i.e. above-canopy PAR, and PARtr is the SunScan measure of transmit-

Table 1. Physical and chemical characteristics of soils in 2012 and 2013 years/sites $(0-30 \mathrm{~cm})$.

\begin{tabular}{|c|c|c|c|c|c|c|c|}
\hline & $\begin{array}{l}\text { Clay } \\
(\%)\end{array}$ & $\begin{array}{l}\text { Silt } \\
(\%)\end{array}$ & $\begin{array}{l}\text { Sand } \\
(\%)\end{array}$ & $\begin{array}{c}\mathrm{pH} \\
(\mathrm{w} / \mathrm{w})\end{array}$ & $\begin{array}{c}\text { Organic matter } \\
(\%)\end{array}$ & $\begin{array}{l}\text { Total nitrogen } \\
\text { (Kjeldahl) } \\
\left(\mathrm{g} \mathrm{kg}^{-1}\right)\end{array}$ & $\begin{array}{l}\text { Available } \\
\text { phosphorus } \\
\text { (Olsen) } \\
\text { (ppm) }\end{array}$ \\
\hline 2012 & 30.7 & 19.4 & 49.9 & 7.9 & 2.4 & 1.6 & 17.8 \\
\hline 2013 & 18.1 & 28.9 & 53.0 & 8.1 & 2.1 & 1.6 & 14.0 \\
\hline
\end{tabular}


ted PAR $\left(\mathrm{mol} \mathrm{m}^{-2} \mathrm{~s}^{-1}\right)$, i.e. below the lowermost green leaf PAR.

Being measurements punctual along the growing season, iPAR values were interpolated with a sigmoid curve as function of the day of year to obtain the estimated seasonal pattern of fractional intercepted PAR. Subsequently, daily iPAR estimates (d_iPAR, MJ m ${ }^{-2} \mathrm{~d}^{-1}$ ) were derived from daily solar radiation (RAD) data recorded at the local weather station. Daily PAR was assumed to be to $50 \%$ of RAD (Monteith and Unsworth, 1990). Then, RUE ( $\mathrm{g} \mathrm{MJ}^{-1}$ ) was determined according to Heaton et al. (2008), as the ratio of the aboveground dry biomass yield at harvest to the cumulated d_iPAR.

Finally, two indices were estimated in order to describe the crop water use: i) the water use efficiency (WUE, $\mathrm{g} \mathrm{L}^{-1}$ ), calculated as the ratio of the aboveground dry yield at harvest to total water received by the crop (i.e. irrigation + precipitation); ii) the water agronomic efficiency (WAE, $\mathrm{g} \mathrm{L}^{-1}$ ), that represent the ability of the plant to increase yield in response to increasing volumes of water (i.e. Delogu et al., 1998; terminology used for nitrogen), calculated as:

$$
W A E=\frac{\left(Y_{\alpha E T P}-Y_{0 E T P}\right)}{\alpha E T P}
$$

where $\alpha \mathrm{Y}_{\text {ETP }}$ represents sorghum dry biomass yield at $\alpha \mathrm{ETP}, \mathrm{Y}_{\mathrm{OETP}}$ is sorghum dry biomass yield at 0 ETP (i.e. rainfed control) and $\alpha$ ETP is the water supply level.

The statistical analysis was performed with $\mathrm{R}$ software ( $\mathrm{R}$ Core Team, 2013) and lme4 package (Bates et al., 2013). Data were analysed using a linear mixed model. Water supply, row spacing configuration and variety were considered fixed variables, while year/site was considered a random variable. Significance was determined using LMERConvenienceFunctions (Tremblay and Ransijn, 2013) which allows to compute upper- and lower-bound P-values for the analysis of variance for each fixed-effect of linear mixed model. Moreover, linear regressions were also applied in order to identify the increase in biomass yield in response to water applied.

\section{Results and discussion}

The study site is characterized by a Mediterranean climate, with precipitation mainly concentrated in autumn and spring. The long-term average (25 years) annual precipitation is about $900 \mathrm{~mm}$ and rainfall during summer months are $47 \mathrm{~mm}$ in June, $24 \mathrm{~mm}$ in July, $33 \mathrm{~mm}$ in August and $99 \mathrm{~mm}$ in September (data not shown). In year 2012, rainfalls from the beginning of June to the end of August were concentrated in 4 days in June and in a single event on August 25 (Figure 1). During the second year (2013) precipitation were unevenly distributed, with some rainfall occurring until the $10^{\text {th }}$ of June, followed by 48 days of no rain, and then by sparse rainfall events ( $\leq 7 \mathrm{~mm}$ each) from late July to late August (Figure 1). The total amount of precipitation the crop received during its cycle equalled to $36.6 \mathrm{~mm}$ and $54.8 \mathrm{~mm}$ in 2012 and 2103 respectively. In both years average air temperature was between 20 and $27^{\circ} \mathrm{C}$, though in some days maximum temperatures exceeded $35^{\circ} \mathrm{C}$. Concerning the ETP demand the two years of study showed quite similar patterns. In fact, in both years the average ETP for the growing season was $4.5 \mathrm{~mm} \mathrm{day}^{-1}$, with daily maximums greater than $5 \mathrm{~mm} \mathrm{day}^{-1}$. Concerning the amount of water supplied through irrigation, the cumulated value in 2012 was $134 \mathrm{~mm}, 268 \mathrm{~mm}$ and 402 $\mathrm{mm}$, and $148 \mathrm{~mm}, 295 \mathrm{~mm}$ and $443 \mathrm{~mm}$ in 2013 for the $50 \mathrm{ETP}, 100 \mathrm{ETP}$ and 150 ETP treatments, respectively. Thus, the total (i.e. rainfall + irrigation) cumulated amount of water that sorghum received during the two growing season ranged from around $170 \mathrm{~mm}$ to $440 \mathrm{~mm}$ and from $203 \mathrm{~mm}$ to $498 \mathrm{~mm}$ in 2012 and 2013 respectively.

About crop phenology (data not shown) we may summarize that: i) in both years no differences were observed between the two energy sorghum varieties. The crop required little more time to emerge in 2013 (19 days) compared to 2012 (11 days) owing to the lower temperatures recorded after sowing. In both 2012 and 2013 leaf development stage was observed until mid-July (around 34 days after emergence), reaching 9 unfolded leaves. Then, a stable phase was observed until mid-August (around 65 days after emergence) when plants were in

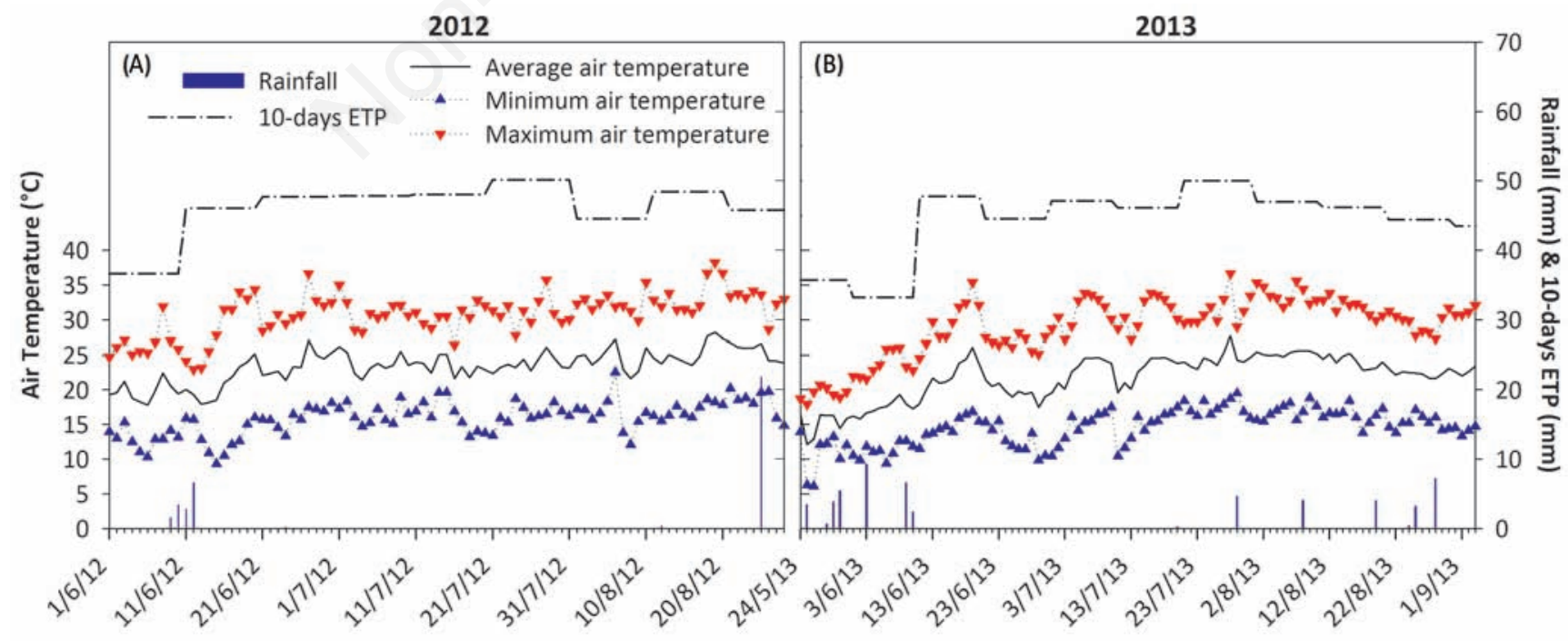

Figure 1. Meteorological data in (A) 2012 and (B) 2013 growing seasons (i.e. from sowing to harvest), at the Interdepartmental Centre of Agro-Environmental Researches (CIRAA) of the University of Pisa (4340' lat. N; $10^{\circ} 23^{\prime}$ long. E), in San Piero a Grado (Pisa), Italy. Evapotranspiration (ETP) is given as the sum of 10 consecutive days (10-days ETP). 
stem elongation phase; ii) RSC seemed to play a role in sorghum phenology only in year 2012. Indeed, in the first year of trial sorghum planted in DR system developed faster compared to the one under SR pattern. On the contrary, no substantial differences were observed in 2013; iii) on average irrigation exerted an important role on crop development. This confirms what reported by Cosentino et al. (2012) who observed a delayed appearance of the main phenological stages when soil water availability is scarce. Nevertheless, in both years the amount of water supplied did not appear to play a major role; sorghum plants under all irrigated treatments were more developed at harvest compared to the rainfed control.

Concerning crop productivity the statistical analysis outlined the importance of the WS levels $(\mathrm{P}<0.0001)$ and the RSC $(\mathrm{P}=0.0023)$ (Table 2). In both years, incrementing volumes of irrigation water led to an increase in total aboveground dry yield, with both stem $(\mathrm{P}<0.0001)$ and leaf $(\mathrm{P}<0.0001)$ components contributing significantly. In 2012 year/site, treatments receiving 50 and 100 ETP achieved a similar total aboveground dry yield ( $15.7 \mathrm{t} \mathrm{ha}^{-1}$ on average). The 0 ETP and 150 ETP yielded 13.3 and $17.8 \mathrm{t} \mathrm{ha}^{-1}$ respectively; thus the crop receiving around $400 \mathrm{~mm}$ (150 ETP) of irrigation water attained a $34 \%$ increase in biomass productivity compared to the rainfed control (Figure 2). During the second year, WS treatments showed more pronounced yield differences, varying from $8.6 \mathrm{t} \mathrm{ha}^{-1}$ in 0 ETP to a maximum above 21.0 tha $^{-1}$ in 150 ETP. Treatments receiving 50 ETP and 100 ETP yielded $11.6 \mathrm{t} \mathrm{ha}^{-1}$ and $17.0 \mathrm{t} \mathrm{ha}^{-1}$ respectively (Figure 2). Therefore, the two-year average increase in dry biomass yield from the rainfed control to the highest water supply level was around $90 \%$. Indeed, it is well reported how energy sorghum can be very productive under specific conditions; for instance, in environments where water is not a limiting factor and growing cycle can extend over 4 months, the crop can easily attain dry biomass yield over $40 \mathrm{t} \mathrm{ha}^{-1}$ (Habyarimana et al., 2004b; Ceotto et al., 2013). However, water resources in Mediterranean environments are often limited and energy sorghum yields may strongly depend upon water supplied by irrigation (Mastrorilli et al., 1999; Berenguer and Faci, 2001). Indeed, Cosentino et al. (2012) highlighted a significant effect of the amount of water distributed in a sweet sorghum trial in southern Italy; the authors reported the lowest dry yields of $7.5 \mathrm{t} \mathrm{ha}^{-1}$ when $80 \mathrm{~mm}$ of water were supplied to the crop from sowing to seedling emergence, against 21.1 and $27.1 \mathrm{t} \mathrm{ha}^{-1}$ when sorghum received $334 \mathrm{~mm}$ and $597 \mathrm{~mm}$ along the

Table 2. Mixed model analysis of variance associated with aboveground dry biomass yield and its partitioning into stem, leaf and panicle dry yields in 2012 and 2013 years/sites in San Piero a Grado (Pisa, Italy). WS, RSC and V are considered fixed variables, while year/site is considered a random variable. P-values represent the lower-bound P-values as determined using LMERConvenienceFunctions (Tremblay and Ransijn, 2013).

\begin{tabular}{|c|c|c|c|c|c|c|c|c|c|}
\hline & \multirow[b]{2}{*}{ Degrees of freedom } & \multicolumn{2}{|c|}{$\begin{array}{l}\text { Total dry biomass yield } \\
(\mathrm{t} \mathrm{ha-1)}\end{array}$} & \multicolumn{2}{|c|}{$\begin{array}{l}\text { Stem dry yield } \\
\quad\left(\mathrm{t} \mathrm{ha}^{-1}\right)\end{array}$} & \multicolumn{2}{|c|}{$\begin{array}{l}\text { Leaf dry yield } \\
\qquad\left(\mathrm{t} \mathrm{ha} \mathrm{a}^{-1}\right)\end{array}$} & \multicolumn{2}{|c|}{$\begin{array}{l}\text { Panicle dry yield } \\
\qquad\left(\mathrm{t} \mathrm{ha}^{-1}\right)\end{array}$} \\
\hline & & F statistics & P-value & F statistics & P-value & F statistics & P-value & F statistics & P-value \\
\hline WS & 3 & 37.7593 & $<0.0001$ & 38.0834 & $<0.0001$ & 22.3703 & $<0.0001$ & 4.6987 & 0.0040 \\
\hline RCS & 1 & 9.7407 & 0.0023 & 8.8303 & 0.0036 & 4.0944 & 0.0454 & 2.9624 & 0.0880 \\
\hline V & 1 & 0.1730 & 0.6783 & 1.6643 & 0.1997 & 0.9085 & 0.3426 & 9.3088 & 0.0029 \\
\hline WS:RCS & 3 & 0.1058 & 0.9565 & 0.1032 & 0.958 & 1.1222 & 0.3433 & 0.6501 & 0.5845 \\
\hline WS:V & 3 & 0.6859 & 0.5625 & 0.7825 & 0.5062 & 2.6279 & 0.0539 & 0.8121 & 0.4898 \\
\hline RCS:V & 1 & 0.2282 & 0.6338 & 0.2099 & 0.6477 & 0.0952 & 0.7582 & 0.5845 & 0.4462 \\
\hline WS:RCS:V & 3 & 1.3828 & 0.2519 & 1.5078 & 0.2165 & 3.0297 & 0.0325 & 0.2529 & 0.8591 \\
\hline
\end{tabular}

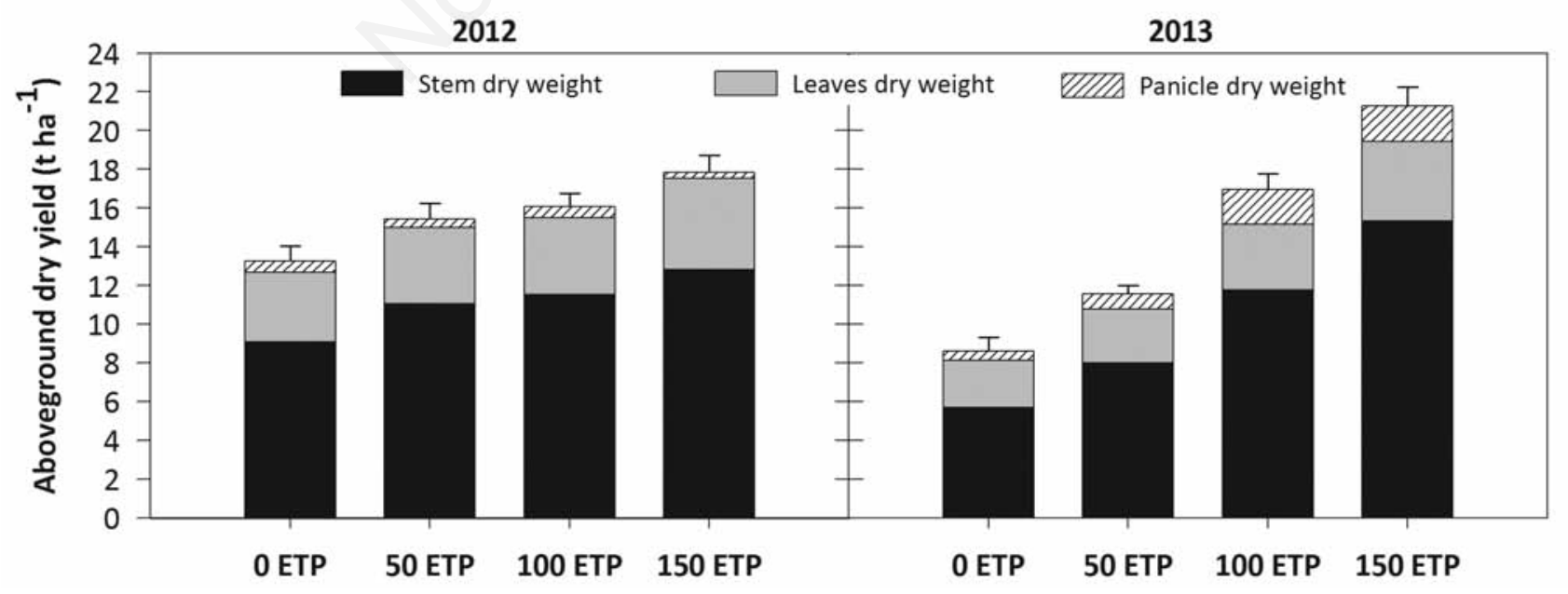

Figure 2. Aboveground dry biomass yield of energy sorghum and its partitioning into stem, leaf and panicle components for the different water supply treatments in 2012 and 2013 years/sites in San Piero a Grado (Pisa, Italy). Bars represent the standard errors (n=4). ETP, evapotranspiration. 
whole growing season, respectively. In southern Italy, Mastrorilli et al. (1995) found sweet sorghum yield around $29 \mathrm{t} \mathrm{ha}^{-1}$ when receiving 550 $\mathrm{mm}$ of water for a growing cycle of 133 days on average, and Garofalo et al. (2011), for shorter growing seasons (92-100 days from sowing to harvest), reported fibre sorghum yield ranging from $19.8 \mathrm{t} \mathrm{ha}^{-1}$ to 34.6 $\mathrm{t} \mathrm{ha} \mathrm{a}^{-1}$ when receiving 270 and $420 \mathrm{~mm}$ of irrigation water. In Greece, sweet sorghum yields over a growing cycle of 165 days varied from 29.8 $\mathrm{t} \mathrm{ha}^{-1}$ to $19.1 \mathrm{t} \mathrm{ha}^{-1}$ switching from no stressed to severe water stressed plants (Dercas and Liakatas, 2007).

Despite the differences in yields between years, a linear response was figured in both the first and the second year of trial between aboveground dry biomass yield and seasonal irrigation water applied (Figure 3 ). Indeed, in the 2012 year/site an increase around $1.1 \mathrm{t} \mathrm{ha}^{-1}$ every 100 $\mathrm{mm}$ increase in water supplied was observed; on the other hand, in the 2013 year/site sorghum increased its dry biomass yield by $2.9 \mathrm{t} \mathrm{ha}^{-1}$ per $100 \mathrm{~mm}$ increase in irrigation water. Our results agree with Farré and Faci (2006) and Berenguer and Faci (2001) who reported a linear relationship between aboveground dry yield and water applied for grain sorghum. Specifically, the former authors reported an increase in grain yield around $1.8 \mathrm{t} \mathrm{ha}^{-1}$ every $100 \mathrm{~mm}$ increase in water supplied (Farré and Faci, 2006), and the latter ones observed an increase in aboveground dry biomass yield around $2.8 \mathrm{t} \mathrm{ha}^{-1}$ per $100 \mathrm{~mm}$ increase in water supplied (Berenguer and Faci, 2001). Nevertheless, the different slopes we recorded in 2012 and 2013 years/sites confirm that the relationship between yield and water supply may vary depending on climate and soil properties (Tolk and Howell, 2003). Since precipitation were not much dissimilar between years, we may postulate that soil properties played a major role in determining sorghum responses to irrigation water applied, which were more pronounced in coarser soils (i.e. 2013 year/site) than in finer textured soils (i.e. 2012 year/site).

Beyond irrigation, DR spacing configuration exerted a role in determining higher sorghum yields compared to the SR system (Table 2). Indeed, in 2012 the DR system yielded about $17 \mathrm{t} \mathrm{ha}^{-1}$, almost $20 \%$ greater than the SR system (around $14.3 \mathrm{t} \mathrm{ha}^{-1}$ ). The second year of trial confirmed the ability of DR sorghum to produce a higher dry yield compared to the SR one, though to a lesser extent (+9\%, 15.2 and 14.0 $\mathrm{t} \mathrm{ha}^{-1}$ in DR and SR respectively). The major contribution to the higher aboveground yield of the DR system was attributable to stem $(\mathrm{P}=0.0036)$ and leaf $(\mathrm{P}=0.0454)$ components (Figure 4).

Some studies investigating grain sorghum and maize responses to RSC highlighted a greater productivity with DR planting pattern. For instance, Fukai and Foale (1988) reported an increase in sorghum grain yield around $22 \%$ adopting DR (i.e. $33 / 163 \mathrm{~cm}$ ) respect to the SR planting pattern. For maize a $4 \%$ increase in grain yield was observed switching from SR to DR planting pattern by Gozubenli et al. (2004) in the eastern Mediterranean region of Turkey. Additional studies conducted in India under dryland conditions have shown that DR planting pattern can increase yields of sorghum, pearl millet and raya (Rao et al., 1977). Concerning energy sorghum, Kresovich and Lawhon (1981) found in Mississippi that narrow row spacing increased sweet sorghum yields by $25 \%$. In Texas, narrow row spacing increased sweet sorghum yields by as much as $50 \%$ (Sim et al., 1981).

The rationale for having higher yields in DR as compared with SR systems may rely on increased early plant competition that can result in a more efficient use of limited moisture (Blum and Nahveh, 1976). However, further studies would be required in Mediterranean environments to evaluate soil moisture dynamics under DR and SR systems. Anyhow, our results suggest that under a warm and dry environment and with a short growing season DR spacing could be a feasible tech-

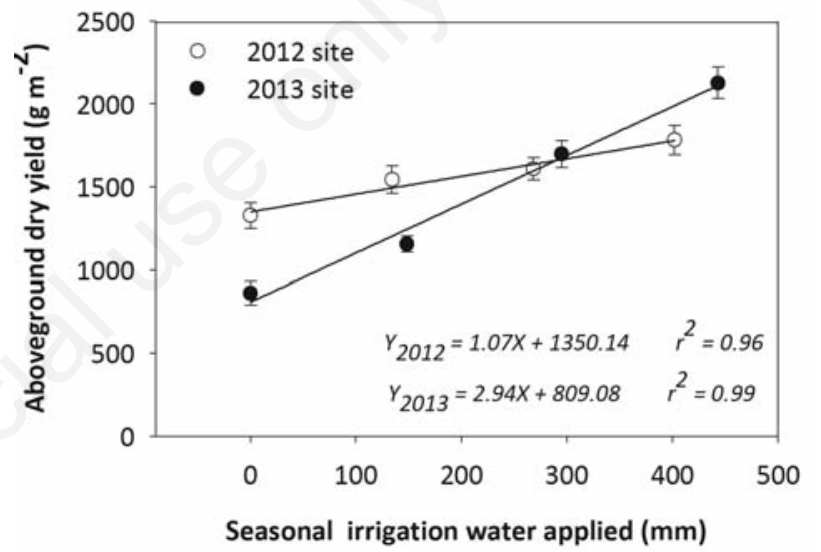

Figure 3. Relationship between aboveground dry biomass yield (Y) and seasonal irrigation water applied (X) for energy sorghum in 2012 and 2013 years/sites in San Piero a Grado (Pisa, Italy). Empty dots represent 2012 year/site and full dots represent 2013 year/site. Error bars represent the standard errors $(n=4)$.

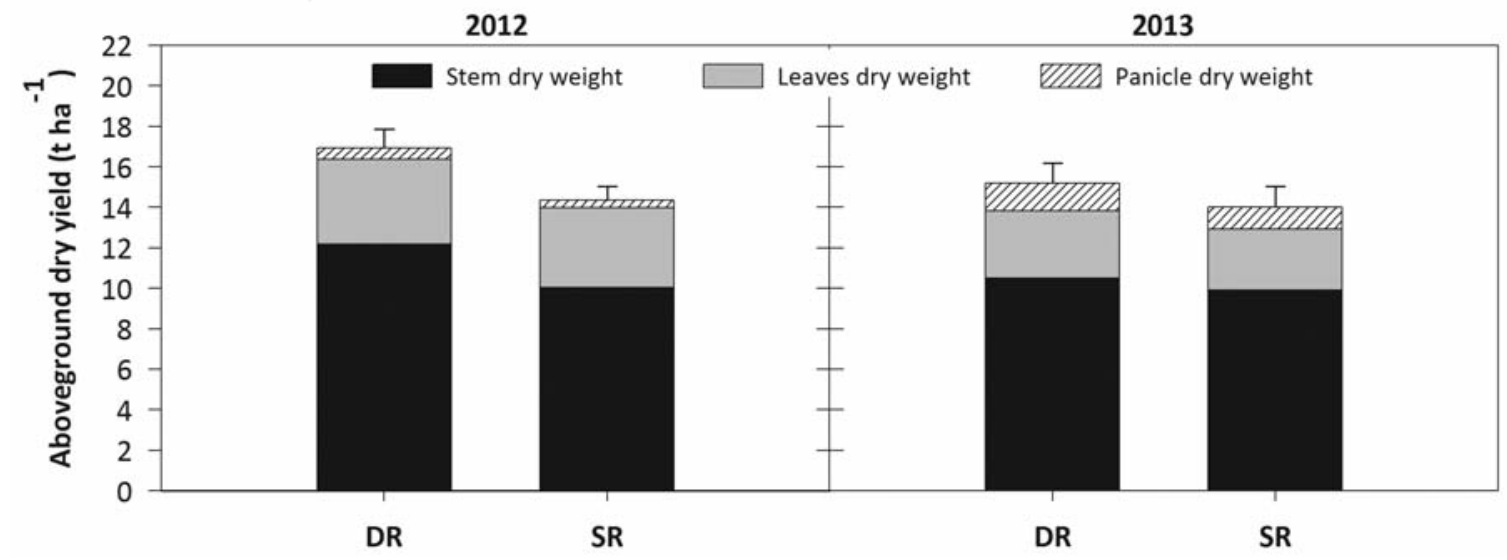

Figure 4. Aboveground dry biomass yield of energy sorghum and its partitioning into stem, leaf and panicle components for the two row spacing configuration treatments in 2012 and 2013 years/sites in San Piero a Grado (Pisa, Italy). Bars represent the standard errors $(n=4)$. 
nical strategy which could led to increasing biomass yield with few or without additional inputs.

In terms of LAI significant differences among treatments are given in Table 3. Specifically, WS, RCS and V had an effect over maximum LAI. Treatments with no irrigation showed the lowest LAI, below $3 \mathrm{~m}^{2} \mathrm{~m}^{-2}$. On the other hand, in both 2012 and 2013 all the irrigated plots had similar values, ranging from 3.5 to $4.8 \mathrm{~m}^{2} \mathrm{~m}^{-2}$ (Table 4).

Previous studies on energy sorghum cultivated in the Mediterranean environment reported maximum LAI ranging from 2.1 to 10.0 (Cosentino et al., 2012; Dolciotti et al., 1998). The large variability reported in literature is associated with the amount of precipitation and irrigation water the crop received during its growing cycle. Indeed, Cosentino et al. (2012) observed that under rainfed control LAI was always lower than irrigated plots, getting values close to zero at harvest. In that experience maximum LAI, averaged for different nitrogen levels, resulted to vary from 2.1 to $4.8 \mathrm{~m}^{2} \mathrm{~m}^{-2}$ in treatments receiving 80 $\mathrm{mm}$ and $597 \mathrm{~mm}$ of water respectively. In Greece, Dercas and Liakatas (2007) reported sweet sorghum LAI responses varying from around 4.8 to $6.5 \mathrm{~m}^{2} \mathrm{~m}^{-2}$ in plots receiving 156 to $458 \mathrm{~mm}$ respectively. Garofalo et al. (2011) in an experience conducted in southern Italy on fibre sorghum reported maximum LAI values from 8 to $6 \mathrm{~m}^{2} \mathrm{~m}^{-2}$ in optimal and stressed water conditions ( 420 vs $270 \mathrm{~mm}$ of applied water).

Furthermore, depending on crop planting pattern maximum LAI resulted to be significantly different in SR and DR systems (Table 4). In 2012 year/site maximum LAI was observed in the DR system with 4.7 $\mathrm{m}^{2} \mathrm{~m}^{-2}$, while SR allowed attaining $3.3 \mathrm{~m}^{2} \mathrm{~m}^{-2}$. Smaller differences in

Table 3. Mixed model analysis of variance associated with crop maximum LAI in 2012 and 2013 years/sites in San Piero a Grado (Pisa, Italy). WS, RSC and V are considered fixed variables, while year/site is considered a random variable. P-values represent the lower-bound P-values as determined using LMERConvenience Functions (Tremblay and Ransijn, 2013).

\begin{tabular}{lccc} 
& Degrees of freedom & F statistics & P-value \\
WS & 3 & 23.6067 & $<0.0001$ \\
RCS & 1 & 62.9107 & $<0.0001$ \\
\hline V & 1 & 10.3145 & 0.0015 \\
WS:RCS & 3 & 4.9817 & 0.0022 \\
\hline WS:V & 3 & 1.4207 & 0.2370 \\
RCS:V & 1 & 1.8085 & 0.1798 \\
\hline WS:RCS:V & 3 & 0.6837 & 0.5627 \\
\hline
\end{tabular}

maximum LAI were recorded in 2013 year/site, when, by the end of the growing season, DR system reached $3.5 \mathrm{~m}^{2} \mathrm{~m}^{-2}$ compared to about $3 \mathrm{~m}^{2}$ $\mathrm{m}^{-2}$ in the SR system.

Finally, also variety exerted a significant influence over maximum LAI, as sweet sorghum showed a higher maximum LAI in both the first and second year of trial (data not shown).

Despite our values match the range reported in literature for maximum LAI data, our generally low values are expected to be related to the very short growing period the crop had (i.e. 81 days from emergence to harvest as averaged between years). Nevertheless, our result suggest that water supply, even though very limited, is useful to better expand sorghum photosynthetic apparatus and may enhance a faster crop growth recovery whenever limiting factors (e.g. drought) disappear.

The cumulated intercepted photosynthetic active radiation (cumulated d_iPAR) and the RUE are given in Table 4. Cumulated d_iPAR directly reflected LAI measurements; thus the treatment with no irrigation cumulated the lowest amount of radiation (417 and 440 MJ in 2012 and 2013 year/site), while on average, after 81 growing days, the irrigated treatments captured from $7 \%$ to $15 \%$ more radiation. On the other hand, the cumulated d_iPAR for the DR system was higher than the SR one $(+12 \%)$ in 2012 year/site, while little lower $(-3 \%)$ in 2013 year/site. This result owed to slightly lower LAI values in DR compared to SR from emergence until 50 days after (data not shown). Concerning RUE, its highest value was registered in the 150 ETP treatments in both years/sites (around $4 \mathrm{~g} \mathrm{MJ}^{-1}$ on average). Conversely, the lowest RUE was observed under the rainfed control ( $2.6 \mathrm{~g} \mathrm{MJ}^{-1}$ on average). 50 ETP and 100 ETP showed intermediate values around $3.2 \mathrm{~g} \mathrm{MJ}^{-1}$.

Considering the two RSC, the DR system gave slightly higher values, with a RUE of 3.4 and $3.3 \mathrm{~g} \mathrm{MJ}^{-1}$ in 2012 and 2013 years/sites. Overall, the RUE we observed is consistent with data on sorghum reported in other studies conducted in Mediterranean environments. Garofalo et al. (2011) reported RUE varying from 2.3 to $3.6 \mathrm{~g} \mathrm{MJ}^{-1}$ depending on the level of water stress the crop was subjected to, and Mastrorilli et al. (1995) observed an average RUE of $3.7 \mathrm{~g} \mathrm{MJ}^{-1}$ in a four-year trial in southern Italy where sorghum received about $550 \mathrm{~mm}$ of water. Under non-limiting conditions Ceotto et al. (2013) found similar RUE, around $3.5 \mathrm{~g} \mathrm{MJ}^{-1}$, while Curt et al. (1998) observed higher values, around $5 \mathrm{~g}$ $\mathrm{MJ}^{-1}$. On the contrary, under sever water stress sorghum RUE may fall to $1.1-1.3 \mathrm{~g} \mathrm{MJ}^{-1}$ owing to a reduction of leaf photosynthetic activity (Dercas and Liakatas, 2007). This behaviour is confirmed by our data as in 2013 site (i.e. soil characterized by a lower water holding capacity) the 0 ETP and 50 ETP treatments showed reduced RUE values $(<2.5$ $\mathrm{g} \mathrm{MJ}^{-1}$ ), proving how important is to calibrate the WS level as depending on soil hydrological properties. Yet, our results confirm the great ability of sorghum to convert the available radiation, despite the short

Table 4. Maximum leaf area index, cumulated photosynthetically active radiation, radiation use efficiency in energy sorghum grown in 2012 and 2013 years/sites in San Piero a Grado (Pisa, Italy). Data are calculated from emergence to harvest. Standard errors are given in brackets.

\begin{tabular}{|c|c|c|c|c|c|c|c|c|c|}
\hline & \multicolumn{4}{|c|}{2012 year/site } & \multicolumn{4}{|c|}{2013 year/site } \\
\hline & & $\begin{array}{l}\text { Aboveground } \\
\text { dry yield } \\
\left(\mathrm{g} \mathrm{m}^{-2}\right)\end{array}$ & $\begin{array}{l}\text { Maximuim } \\
\text { LAI } \\
\left(\mathrm{m}^{2} \mathrm{~m}^{-2}\right)\end{array}$ & $\begin{array}{l}\text { Cumulated } \\
\text { d_iPAR } \\
\left(\mathrm{MJ} \mathrm{m}^{-2}\right)\end{array}$ & $\begin{array}{c}\text { RUE } \\
\left(\mathrm{g} \mathrm{MJ}^{-1}\right)\end{array}$ & $\begin{array}{l}\text { Aboveground } \\
\text { dry yield } \\
\left(\mathrm{g} \mathrm{m}^{-2}\right)\end{array}$ & $\begin{array}{l}\text { Maximum } \\
\text { LAI } \\
\left(\mathrm{m}^{2} \mathrm{~m}^{-2}\right)\end{array}$ & $\begin{array}{c}\text { Cumulated } \\
\text { d_iPAR } \\
\left(\mathrm{MJ} \mathrm{m}^{-2}\right)\end{array}$ & $\begin{array}{c}\text { RUE } \\
\left(\mathrm{g} \mathrm{MJ}^{-1}\right)\end{array}$ \\
\hline WS & $\begin{array}{c}0 \\
50 \\
100 \\
150\end{array}$ & $\begin{array}{l}1327( \pm 76.2) \\
1542( \pm 82.9) \\
1608( \pm 67.5) \\
1783( \pm 88.4)\end{array}$ & $\begin{array}{l}3.0( \pm 0.17) \\
4.7( \pm 0.24) \\
4.2( \pm 0.20) \\
4.2( \pm 0.15)\end{array}$ & $\begin{array}{l}417 \\
497 \\
467 \\
479\end{array}$ & $\begin{array}{l}3.2( \pm 0.06) \\
3.1( \pm 0.05) \\
3.4( \pm 0.03) \\
3.7( \pm 0.01)\end{array}$ & $\begin{array}{l}861( \pm 70.1) \\
1156( \pm 46.4) \\
1698( \pm 80.4) \\
2127( \pm 95.9)\end{array}$ & $\begin{array}{l}2.1( \pm 0.23) \\
3.4( \pm 0.22) \\
3.4( \pm 0.21) \\
4.0( \pm 0.25)\end{array}$ & $\begin{array}{l}440 \\
456 \\
453 \\
503\end{array}$ & $\begin{array}{l}2.0( \pm 0.09) \\
2.5( \pm 0.04) \\
3.7( \pm 0.07) \\
4.2( \pm 0.19)\end{array}$ \\
\hline RSC & $\begin{array}{l}\text { DR } \\
\text { SR }\end{array}$ & $\begin{array}{l}1695( \pm 65.2) \\
1435( \pm 49.4)\end{array}$ & $\begin{array}{l}4.7( \pm 0.16) \\
3.3( \pm 0.10)\end{array}$ & $\begin{array}{l}494 \\
439\end{array}$ & $\begin{array}{l}3.4( \pm 0.05) \\
3.3( \pm 0.06)\end{array}$ & $\begin{array}{c}1520( \pm 106.2) \\
1401( \pm 97.4)\end{array}$ & $\begin{array}{l}3.5( \pm 0.18) \\
3.0( \pm 0.18)\end{array}$ & $\begin{array}{l}458 \\
470\end{array}$ & $\begin{array}{l}3.3( \pm 0.02) \\
3.0( \pm 0.07)\end{array}$ \\
\hline
\end{tabular}

LAI, leaf area index; __iPAR, cumulated photosynthetically active radiation; RUE, radiation use efficiency. 
Table 5. Water use efficiency and water agronomic efficiency in energy sorghum for 2012 and 2103 years/sites of experimentation (data averaged over RSC and V) and for RSC (data averaged over year/site and V) in San Piero a Grado (Pisa, Italy). Standard errors are given in brackets.

\begin{tabular}{|c|c|c|c|c|c|c|}
\hline & WS level & $\begin{array}{l}\text { Aboveground dry yield } \\
\qquad\left(\mathrm{g} \mathrm{m}^{-2}\right)\end{array}$ & $\begin{array}{l}\text { Irrigation } \\
\text { (mm) }\end{array}$ & $\begin{array}{l}\text { Rainfall } \\
\text { (mm) }\end{array}$ & $\begin{array}{l}\text { WUE } \\
\left(\mathrm{g} \mathrm{L}^{-1}\right)\end{array}$ & $\begin{array}{c}\text { WAE } \\
\left(\Delta \mathrm{g} \mathrm{L}^{-1}\right)\end{array}$ \\
\hline 2012 & $\begin{array}{c}0 \\
50 \\
100 \\
150\end{array}$ & $\begin{array}{l}1327( \pm 76.2) \\
1542( \pm 82.9) \\
1608( \pm 67.5) \\
1783( \pm 88.4)\end{array}$ & $\begin{array}{l}134 \\
268 \\
402\end{array}$ & 36.6 & $\begin{array}{l}9.0( \pm 0.16) \\
5.3( \pm 0.05) \\
4.1( \pm 0.01)\end{array}$ & $\begin{array}{l}1.6( \pm 0.13) \\
1.0( \pm 0.11) \\
1.1( \pm 0.13)\end{array}$ \\
\hline 2013 & $\begin{array}{c}0 \\
50 \\
100 \\
150\end{array}$ & $\begin{array}{l}861( \pm 70.1) \\
1156( \pm 46.4) \\
1698( \pm 80.4) \\
2127( \pm 95.9)\end{array}$ & $\begin{array}{l}148 \\
295 \\
443 \\
\end{array}$ & 54.8 & $\begin{array}{l}5.7( \pm 0.09) \\
4.9( \pm 0.09) \\
4.3( \pm 0.19)\end{array}$ & $\begin{array}{l}2.0( \pm 0.77) \\
2.8( \pm 0.46) \\
2.9( \pm 0.36)\end{array}$ \\
\hline $\mathrm{DR}$ & $\begin{array}{c}0 \\
50 \\
100 \\
150\end{array}$ & $\begin{array}{c}1191( \pm 90.2) \\
1454( \pm 73.1) \\
1719( \pm 122.5) \\
2065( \pm 131.1)\end{array}$ & $\begin{array}{l}141 \\
282 \\
423\end{array}$ & 45.7 & $\begin{array}{l}7.8( \pm 0.39) \\
5.3( \pm 0.37) \\
4.4( \pm 0.28)\end{array}$ & $\begin{array}{l}1.9( \pm 0.66) \\
1.9( \pm 0.39) \\
2.1( \pm 0.42)\end{array}$ \\
\hline SR & $\begin{array}{c}0 \\
50 \\
100 \\
150\end{array}$ & $\begin{array}{c}997( \pm 55.5) \\
1244( \pm 38.7) \\
1586( \pm 63.6) \\
1845( \pm 65.3)\end{array}$ & $\begin{array}{l}141 \\
282 \\
423\end{array}$ & 45.7 & $\begin{array}{l}6.7( \pm 0.21) \\
4.8( \pm 0.19) \\
3.9( \pm 0.14)\end{array}$ & $\begin{array}{l}1.7( \pm 0.23) \\
2.1( \pm 0.14) \\
2.0( \pm 0.18)\end{array}$ \\
\hline
\end{tabular}

WUE, water use efficiency; WAE, water agronomic efficiency.

growing period the crop had to accumulate dry matter (around 80 days from emergence).

The water use efficiency in 2012 and 2013 years/sites ranged between 9.0 to $4.1 \mathrm{~g} \mathrm{~L}^{-1}$ (Table 5). Our WUE data agree with values commonly given in literature for sorghum. For instance, sorghum WUE ranges from 4.6 to $6.1 \mathrm{~g} \mathrm{~L}^{-1}$ (Curt et al., 1995), from 4.5 to $6.1 \mathrm{~g} \mathrm{~L}^{-1}$ (Cosentino, 1996), from 5.5 to $6.0 \mathrm{~g} \mathrm{~L}^{-1}$ (Mastrorilli et al., 1999), from 4.4 to $8.2 \mathrm{~g} \mathrm{~L}^{-1}$ (Garofalo et al., 2011), from 4.0 to $5.0 \mathrm{~g} \mathrm{~L}^{-1}$ (Cosentino et al., 2012) as depending on agro-climatic conditions and WS level. Furthermore, the crop showed an inverse relationship between WUE and irrigation water applied (Table 5). Indeed, switching from 50 ETP to 150 ETP WUE decreased by $43 \%$ on average. This confirms the ability of sorghum to improve its WUE when subjected to drought conditions (Zegada-Lizarazu et al., 2012), though it has to be noted that our WUE values do not take into account water the crop may have directly used from the water table and/or water losses due to percolation. Finally, discriminating for the two RSC, it was possible to show how sorghum planted in DR was generally more efficient in its use of water, possibly due to a easier water uptake from roots closer to the drip line (Eugenio Coelho and Or, 1999) and/or early plant competition (Blum and Naveh, 1976). Finally, we calculated WAE, which allows normalizing the water used by the crop and obtaining a marginal gain in yield. Our WAE results highlighted the great potential of sorghum to boost its biomass in response to water supply increments. In fact, in both 2012 and 2013 years/sites energy sorghum was able to maintain a very efficient use of water over a wide range of water supply, from $50 \%$ up to $150 \%$ restoration of the potential evapotranspiration (two-year average of 1.8, 1.9 and $2.0 \Delta \mathrm{g} \mathrm{L}^{-1}$ (WAE, as in Table 5) in 50 ETP, 100 ETP and 150 ETP, respectively). Moreover, this behaviour was particularity emphasized in the 2013 site where the soil had lower clay content than the 2012 site ( $+45 \%$ from 50 ETP to 150 ETP).

\section{Conclusions}

This study confirmed sorghum as a species with a high ability to withstand drought stress, thus being a very robust and adaptable crop.
The crop resulted to have a very rapid growth; in fact, although biomass accumulation period was very short (about 80 days from emergence to harvest), sorghum showed a good productive potential. The effect of the irrigation was shown even at low volumes of water and particularly marked in coarse soils. The trial also highlighted how row spacing configuration could be an important factor in determining crop productivity in short growing seasons, such those devoted to double-cropping systems. Therefore, double row planting pattern could be a feasible technical option to increase biomass yields with few or without additional costs for farmers. Finally, beyond the high water use efficiency, around $5.6 \mathrm{~g} \mathrm{~L}^{-1}$ on average, interesting was the WAE datum, i.e. the ability of the plant to increase the biomass yield in response to the applied water. In fact, beyond the tolerance to dry conditions, our result highlighted sorghum ability to maintain a very efficient use of water over a wide range of water supply, from $50 \%$ up to $150 \%$ restoration of the potential evapotranspiration.

\section{References}

Allen RG, Pereira LS, Raes D, Smith M, 1998. Crop evapotranspirationGuidelines for computing crop water requirements - FAO Irrigation and drainage paper 56. FA0, Rome, Italy.

Amaducci S, Monti A, Venturi G, 2004. Non-structural carbohydrates and fibre components in sweet and fibre sorghum as affected by low and normal input techniques. Ind. Crop. Prod. 20:111-8.

Antonopoulou G, Gavala HN, Skiadas IV, Angelopoulos K, Lyberatos G, 2008. Biofuels generation from sweet sorghum: Fermentative hydrogen production and anaerobic digestion of the remaining biomass. Bioresource Technol. 99:110-9.

Barbanti L, Grandi S, Vecchi A, Venturi G, 2006. Sweet and fibre sorghum (Sorghum bicolor (L.) Moench), energy crops in the frame of environmental protection from excessive nitrogen loads. Eur. J. Agron. 25:30-9.

Bates D, Maechler M, Bolker B, 2013. Ime4: Linear mixed-effects models using S4 classes. R package version 0.999999-2. Available from: 
http://CRAN.R-project.org/package=lme4

BBCH Monograph, 2001. Growth stages of mono- and dicotyledonous plants. 2nd ed. Uwe Meier, Federal Biological Research Centre for Agriculture and Forestry, Bonn, Germany.

Berenguer MJ, Faci JM, 2001. Sorghum (Sorghum bicolor L. Moench) yield compensation processes under different plant densities and variable water supply. Eur. J. Agron. 15:43-55.

Blum A, Naveh M, 1976. Improved water use efficiency in dryland grain sorghum by promoted plant competition Agron. J. 68:111-6.

Ceotto E, Di Candilo M, Castelli F, Badeck F-W, Rizza F, Soave C, Volta A, Villani G, Marletto V, 2013. Comparing solar radiation interception and use efficiency for the energy crops giant reed (Arundo donax L.) and sweet sorghum (Sorghum bicolor L. Moench). Field Crop. Res. 149:159-66.

Cosentino SL, 1996. Crop physiology of sweet sorghum. pp 30-41 in Proc. First European Seminar on Sorghum for Energy and Industry, Tulose, France.

Cosentino SL, Mantineo M, Testa G, 2012. Water and nitrogen balance of sweet sorghum (Sorghum bicolor Moench (L.)) cv. Keller under semi-arid conditions. Ind. Crop. Prod. 36:329-42.

Curt MD, Fernandez J, Martinez M, 1995. Productivity and water use efficiency of sweet sorghum (Sorghum bicolor (L.) Moench) cv. "Keller" in relation to water regime. Biomass Bioenerg. 8:401-9.

Curt MD, Fernandez J, Martinez M, 1998. Productivity and radiation use efficiency of sweet sorghum (Sorghum bicolor (L.) Moench) cv. Keller in central Spain. Biomass Bioenerg. 14:169-78.

Delogu G, Cattivelli L, Pecchioni N, De Falcis D, Maggiore T, Stanca AM, 1998. Uptake and agronomic efficiency of nitrogen in winter barley and winter wheat. Eur. J. Agron. 9:11-20.

Dercas N, Liakatas A, 2007. Water and radiation effect on sweet sorghum productivity. Water Resour. Manag. 21:1585-600.

Dolciotti I, Mambelli S, Grandi S, Venturi G, 1998. Comparison of two sorghum genotypes for sugar and fiber production. Ind. Crop. Prod. 7:265-72.

El Bassam N, 1998. Energy plant species: their use and impact on environment and development. Ed. Earthscan, London, UK.

Eugenio Coelho F, Or D, 1999. Root distribution and water uptake patterns of corn under surface and subsurface drip irrigation. Plant Soil 206:123-36.

Farré I, Faci JM, 2006. Comparative response of maize (Zea mays L.) and sorghum (Sorghum bicolor L. Moench) to deficit irrigation in a Mediterranean environment. Agr. Water Manage. 83:135-43.

Fukai S, Foale MA, 1988. Effect of row spacing on growth and grain yield of early and late sorghum cultivars. Aust. J. Exp. Agr. 28:771-7.

Garofalo P, Vonella AV, Ruggieri S, Rinaldi M, 2011. Water and radiation use efficiencies of irrigated biomass sorghum in a Mediterranean environment. Ital. J. Agron. 6:133-9.

Godsey CB Linneman J, Bellmer D, Huhnke R, 2012. Developing row spacing and planting density recommendations for rainfed sweet sorghum production in the southern plains. Agron. J. 104:280-6.

Goff BM, 2010. Double-cropping sorghum for biomass production. Graduate Theses and Dissertations. Iowa State University, Ames, IA, USA.

Gozubenli H, Kilinc M, Sener 0, Konuskan 0, 2004. Effects of single and twin row planting on yield and yield components in maize. Asian J. Plant Sci. 3:203-6.

Habyarimana E, Bonardi P, Laureti D, Di Bari V, Cosentino S, Lorenzoni C, 2004a. Multilocational evaluation of biomass sorghum hybrids under two stand densities and variable water supply in Italy. Ind. Crop. Prod. 20:3-9.
Habyarimana E, Laureti D, De Ninno M, Lorenzoni C, 2004b. Performances of biomass sorghum [Sorghum bicolor (L.) Moench] under different water regimes in Mediterranean region. Ind. Crop. Prod. 20:23-8.

Heaton EA, Dohleman FG, Long SP, 2008. Meeting US biofuel goals with less land: the potential of Miscanthus. Glob. Change Biol. 14:2000-14.

Heggenstaller AH, Anex RP, Liebman M, Sundberg DN, Gibson LR, 2008. Productivity and nutrient dynamics in bioenergy double-cropping systems. Agron. J. 100:1740-8.

Kresovich S, Lawhon WT, 1981. Agronomic research and development needs in sugar crops. pp 69-71 in Proc. American Society of Sugar Cane Technologists, Baton Rouge, LA, USA.

Martin PM, Kelleher FM, 1984. Effects of row spacing and plant population on sweet sorghum yield. Aust. J. Exp. Agric. Anim. Husb. 24:386-90.

Mastrorilli M, Katerji N, Rana G, 1999. Productivity and water use efficiency of sweet sorghum as affected by soil water deficit occurring at different vegetative growth stages. Eur. J. Agron. 11:207-15.

Mastrorilli M, Katerji N, Rana G, Steduto P, 1995. Sweet sorghum in Mediterranean climate: radiation use and biomass water use efficiencies. Ind. Crop. Prod. 3:253-60.

Monti A, Venturi G, 2003. Comparison of the energy performance of fibre sorghum, sweet sorghum and wheat monocultures in northern Italy. Eur. J. Agron. 19:35-43.

Montieth JL, Unsworth MH, 1990. Principles of environmental physics. Routledge, Chapman and Hall, New York, NY, USA.

Pin M, Vecchiet A, Picco D, 2011. Diffusion of a sustainable EU model to produce 1st generation ethanol from sweet sorghum in decentralised plants - Technical Manual. Ed. Poligrafiche San Marco, Cormons, Gorizia, Italy.

R Core Team, 2013. R: A language and environment for statistical computing. R Foundation for Statistical Computing, Vienna, Austria. Available from: http://www.R-project.org/

Rao MR, Rego TJ, Willey RW, 1977. Plant population and spatial arrangement effects in monocrops and intercrops in rainfed areas. In Seminar on Dry Farming organised by the Institution of Agricultural Technologists, Bangalore, India.

Shakarami G, Rafiee M, 2009. Response of corn (Zea mays L.) to planting pattern and density in Iran. Am. Eurasian J. Agric. Environ. Sci. 5:69-73.

Sim A, Reeves Jr., Smith BA, Hipp BW, 1981. Narrow row spacings of sweet sorghum in Texas. Page 160 in Proc. American Society of Sugar Cane Technologists, Baton Rouge, LA, USA.

Tolk JA, Howell TA, 2003. Water use efficiencies of grain sorghum grown in three USA southern Great Plains soils. Agric. Water Manage. 59:97-111.

Tremblay A, Ransijn J, 2013. LMERConvenienceFunctions: a suite of functions to back-fit fixed effects and forward-fit random effects, as well as other miscellaneous functions. $\mathrm{R}$ package version 2.0. Available from: http://CRAN.R-project.org/package=LMERConve nienceFunctions

Wallace J, 2000. Increasing agricultural water use efficiency to meet future food production. Agr. Ecosyst. Environ. 82:105-19.

Zegada-Lizarazu W, Monti A, 2012. Are we ready to cultivate sweet sorghum as a bioenergy feedstock? A review on field management practices. Biomass Bioenerg. 40:1-12.

Zegada-Lizarazu W, Zatta A, Monti A, 2012. Water uptake efficiency and above- and belowground biomass development of sweet sorghum and maize under different water regimes. Plant Soil 351:47-60. 